\title{
Identity by the object: an educational project using portrait and self-portrait to build identities
}

Alice Bajardi alicebajardi@gmail.com

Dpt. de Didáctica de la Expresión Musical, Plástica y Corporal. Universidad de Granada, España

Reference

Bajardi, Alice; (2012) "Identity by the object: an educational project using portrait and self-portrait to build identities", p. 73-77. In: Barbosa, Helena; Quental, Joana [Eds]. Proceedings of the 2nd International Conference of Art, Illustration and Visual Culture in Infant and Primary Education. São Paulo: Blucher, 2015 ISSN 2318-695X, ISBN: 978-989-98185-0-7 DOI 10.5151/edupro-aivcipe-15

Abstract

The main topic of this work is the individual identity and its relationships with the society achieved by the self-portrait and the portrait. We proposed the educational project "Identity by the object" to students of a public primary and secondary school using the portrait and the selfportrait to promote reflection on identity and to relate it to the vision of others.

The methodology used for this educational proposal is formed by: a theoretical introduction to portrait and self-portrait and the use of metaphor, the experience of the self-portrait and the portrait using objects, the pose in front of the photographic medium with these objects, the print of these photos on t-shirts and, finally, a public exposition to promote dialogue and the confront with the visitors representing society.

This project developed the student's abilities to understand the artistic language, especially contemporary and contributed to overcome stereotypes of representation, and enabled to students to develop their identities.

art education, identity, portrait, self portrait, metaphor

Introduction

This paper deals with the individual identity and its relations with society through the educational use of self-portraits and portraits. The representation of yourself and others is often used in education through various media (e.g. painting, photography, writing) and in different educational contexts (e.g. schools, education departments in museums, private courses). In fact, self-portraits and portraits validity is known because it allows to stimulate reflection on yourself and others, identifying yourself and others both physically and psychologically (Francucci and Vassalli, 2005; Bertolini, 2009). It 's important to work not only with self-portrait but also with the portrait because the "individual self" is defined both in relation to ourselves and to another, because man and woman are not only "individual beings " but also "collective beings" (Cionchin, 2009). The portrait and the self-portrait are often used with children because they are building its identity and affirming their "self" in society. To receive a portrait enriched the identity of the receiver because, thanks to external points of view, it provides new subjective interpretations and the possibility to reprocess them (Dallari and Francucci, 1998).

We propose the portraits and self-portraits using the object as a metaphor, as is done in poetry but applied to the visual language. Dallari and Francucci (1998) speak in a psycho-pedagogical way of the "own" or "mine", not only in the material sense but in the sense of affection, ties, habits, that are very important for the development and consolidation of personal identity. 
$2^{\text {nd }}$ International Conference Art, Illustration and Visual Culture in Infant and Primary Education
For these reasons we proposed to pupils of an Italian primary and secondary school an educational path called "The identity by the object" using objects as metaphor to promote reflection on their identity in relation to themselves and to others.

The specific objectives of the educational activity "The identity by the object" are:

- To provide the basis for reading images and works of art, developing the capacity of reasoning, observation and comparison;

- To develop the skills of observation and interaction with reality as an artistic process;

- To encourage reflection on own identity in relation with others through the use of metaphor and photography;

- To develop the capacity of interaction and collaboration in the team work and encourage the socialization also outside the classroom;

- To overcoming stereotypes of representation and self-representation through the use of unconventional tools and methodologies.

The project included a brief theoretical introduction on the use of the portrait and of the selfportrait given by projection of images and a brainstorming session with the aim to develop the student's ability to understand the language of modern and contemporary art. The activity continued with the choice of objects useful as a metaphor for the self-portrait and portrait by each pupil and his classmate, respectively. Then, each pupil posed with his objects in front of the photographic medium, and finally an exhibition open to the public of the images printed on shirts was mounted.

\section{The didactic experience "The identity by the object"}

"The identity through the object" is a educational proposal that was developed in an Italian primary and secondary school. The activity consists of four phases: a brief theoretical introduction conducted at school, the research of objects achieved by pupils at home, the photos with these objects and finally the exhibition of the works carried out, both happened at school.

The theoretical introduction consisted in a presentation of portraits and self portraits from the end of 1400 to the present, which was achieved by a projection of images selected and organized into categories of meaning, such as the likelihood, the social-status, the double (mirror and shadow), the fingerprint, the metaphor, the memory and the "mine" through personal effects (Spadoni, 2003; Bertolini, 2009). We shown self-portraits and portraits made by artists who used painting, photography, and installation, such as Piero della Francesca, Tiziano, Parmigianino, Ugo Mulas, Penone, Magritte, Arman and Tony Cragg. The information about the works of art did not come unilaterally from the teacher but were provided by the pupils that, arranged in a semicircle, described and interpreted the images guided by the teacher. In this phase it was also explained the meaning and use of metaphor, mainly through the images but also with examples of poetry.

Figures 1. T-shirts with portraits and self-portraits of students hanging on two threads for the final exhibition of the works. (May, 2009). Bologna, Italy. Source: personal.

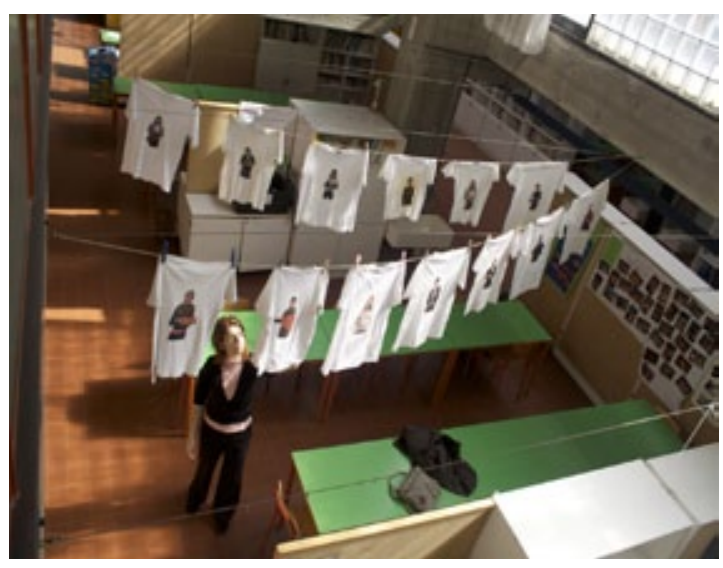


$2^{\text {nd }}$ International Conference Art, Illustration and Visual Culture in Infant and Primary Education
${ }^{\circ}$ Congreso Internaciona

Arte, llustración y Cultura Visual en Educación Infantil y Primaria
Congresso Internaciona

de Arte, Ilustração e Cultura Visual

na Educação Infantil e Primária

\section{Results}

Figures 2.. On the left the self-portraits and on the right the portraits of the students (May, 2009). Bologna, Italy. Source: personal.
During the second phase we proposed to work in pairs to experience the self-portrait and the portrait by an object. The research of the object happened at home and not in the classroom to avoid it the classmate influence on pupil and to have a wide choice of objects connected to student's living. The students searched for objects that were representative for self-portraits and portraits in their homes and in the houses of their classmates, respectively. Furthermore, written motivations for the choice were requested to students.

The third phase took place in the classroom where each student poses in front of the photographic medium firstly with the object chosen by himself as self-portrait and then with that one chosen by a classmate as portrait. Finally, the students set up an open exhibition of their self-portraits and portraits printed on t-shirts front and back, respectively (figure 1).

The first phase of "The identity by the object" was characterized by a non-standard art history lesson. In fact, the teacher did not explained to students an artistic movement showing a few images in the textbook. In a multimedia classroom the students, arranged in a semicircle, interpreted projected portraits and self-important relevant for our educational path without the use of text. Students participated asking or commenting with enthusiasm, curiosity and humor, while the teacher guided the flow of ideas coming out from the students.
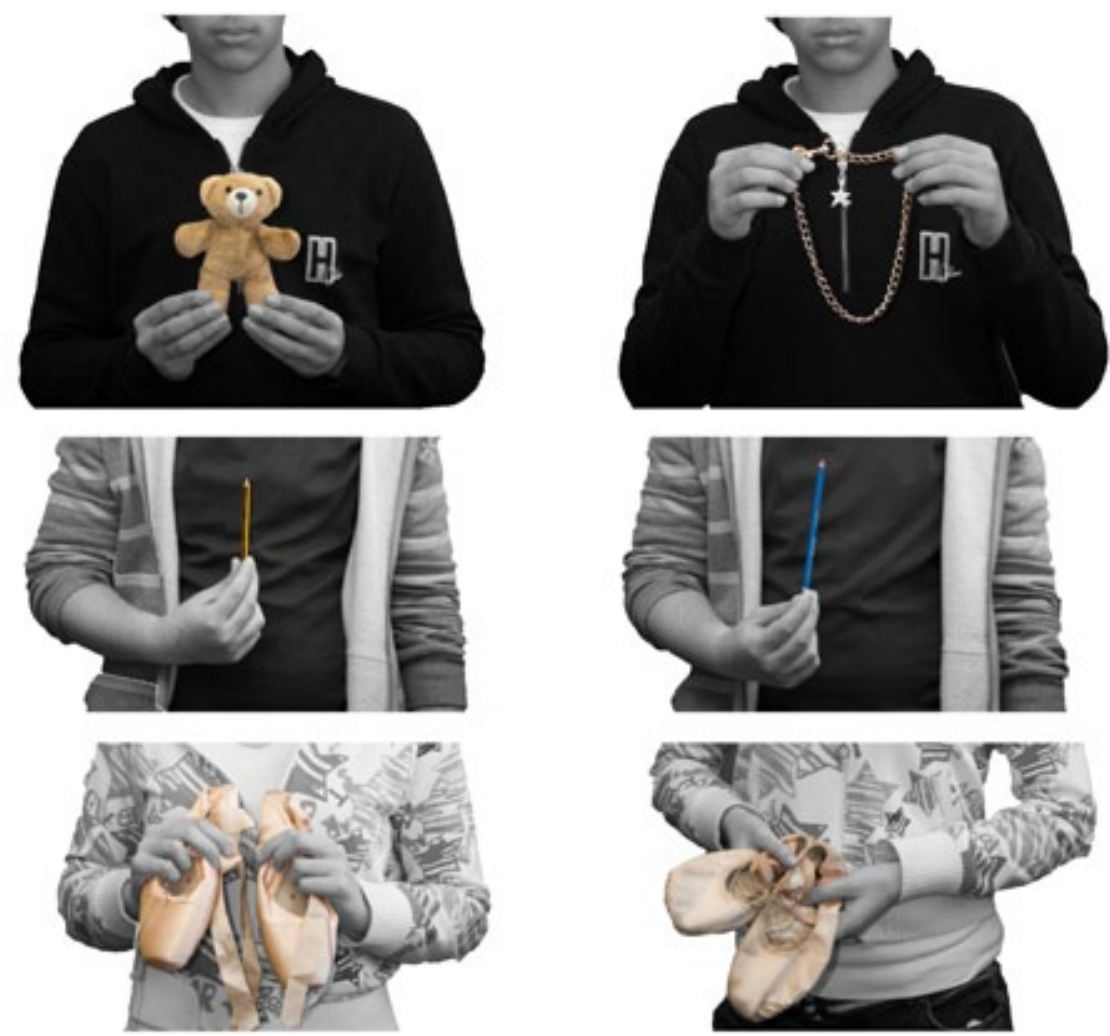

During the second phase of the educational path most of the students did original choices. Some of the students who did less original choices were absent during the theoretical introduction to the subject. Each student gave written reasons for his choices, sometimes identifying the positive and negative characteristics of himself and his classmate. The objects for self-portrait were chosen mostly on the base of students' passions and memories related to these objects. While the choice of objects to create classmate portraits was mostly metaphorical. Often, some strong contradiction occurred between self-portrait and portrait of a student. This is the case of a pupil self-represented with a teddy bear and portrayed as a heavychain-necklace (figures 2). Only in two cases a student was represented in a portrait with similar objects and motivations chosen by yourself for the self-portrait. This is the case of portraits and self-portraits realized by a pencil and dancing shoes. (figures 2). 


\section{Discussions and conclusions}

During the third phase of the project the students, some timidly, others with more security, have posed in the classroom with their objects to take picture. Most of the students were surprised to discover the objects which their classmate chosen for the portrait.

Finally, the photos were printed on T-shirts by placing the self-portraits and portraits, respectively, on the front and on the back of the shirts and some students wore them. The final phase consisted in an exhibition with all shirts hanging with clothespins in two wires, as clothes to dry (figure 1). The exhibition was organized in the school and open to the public promoting curiosity and interest in teachers and students of other classes. This allowed the communication and exchange of ideas and experience between teachers and students and among students.

The didactic activity "The identity by the object" was greeted by pupils from the outset in a enthusiastic way. The theoretical part of the introduction that could result complex for students because it contained many images and concepts was experienced by the students pleasantly and with participation and humor. Probably, this occurred because the students appreciated that we went to an appropriate classroom to projecting big images and we didn't use the textbook. But above all because was not the teacher to speak unilaterally to the silent/sleeping class, but student had to interpret the images and to provide information aided by the teacher. Furthermore, students were warned, with practical examples, that the introduction would have been essential to the realization of the practical activities of the educational path. This theoretical introduction is important not only to provide to students the skills necessary to read images and works of art and to improve knowledge of the artistic heritage, but also to develop practical activity in a creative and conscious way avoiding representative stereotypes (Bajardi and Álvarez Rodríguez, 2012a, 2012b).

Students, choosing objects representative of themselves and of their classmate, implemented a selection based on formal and aesthetic elements, memories, feelings and direct or indirect experiences. This gave to the students the possibility to develop their skills of observation and analysis of reality as in the artistic investigation. Furthermore, this analysis and self-analysis was useful to develop the identity of the student who reflected on himself and on the others, through fun activities, and expanded his point of view thanks to the contribution of classmates and to the moment of the collective exchange. The choice of the pupil was analyzed, confirmed and emphasized by himself during the ensemble of phases, the given motivations, the pose, the wearing and the public exhibition.

The final exhibition generated surprise and enthusiasm both among the students who participated in activities and the schoolmates from other classes. Also teachers, included the school director, shown curiosity and were pleased about techniques and contents of this educational path. The phase of the final exhibition of an art-educational path in general is an integrant and important moment because it usually generates amazement (the "aesthetic amazement", Dallari, 1998) not only in the visitors but also in the participants that experienced the workshop. Finally, the exhibition facilitates further reflections on their work, the self-analysis and the exchange and communication with others.

This educational path contributed, through the use of non-traditional tools and methodologies in schools, to overcome stereotypes of self-representation and representation, and enabled to students to learn more about themselves and their classmates going beyond the surface. Thus, it is important to continue to investigate and experiment in this sense in art education to establish effective guidelines. It would also be interesting and useful to extend this type of investigation in art education to teacher training.

\section{References}

Bajardi, A. and Álvarez Rodríguez, D. (2012a). Art education to develop creativity and critical skills in digital society: integrating the tradition in an e-learning environment, Communications of the International Conference The Future of Education Conference Proceedings 2012, Milan: Simonelli Editor (2012), 
$2^{\circ}$ Congresso Internacional

de Arte, Ilustração e Cultura Visual

na Educação Infantil e Primária

II International Conference The Future of education, Florence (2012) Available in: http://www.pixelonline.net/edu_future2012/common/download/Paper_pdf/709-AE23-FP-Bajardi-FOE2012.pdf

Bajardi, A. and Álvarez Rodríguez, D. (2012b), La performance como experiencia educativa en la Enseñanza Secundaria: un medio para fomentar la motivación y la creatividad, Communications of the International Conference Arte, Educación y cultura: Aportaciones desde la periferia, Jaén: Ilustre Colegio Oficial de Doctores y Licenciados en Bellas Artes de Andalucía (2012), IV International Conference of Visual and Artistic Education, Jaén (2012) Available in: <http://www. educacionartistica.es/aportaciones/1_comunicaciones/intervencion_reconstruccion/190_bajardi_ alvarez_performance-secundaria.pdf>

Cionchin, A. C. (2009). Interrogazioni sull'identità di "Qualcun altro". in Philologica Jassyensia, n. 2/2009, pp. 99-109 [Consulted in May 2012]. Available in: http://philologica-jassyensia.ro/upload/V_2_Cionchin. pdf

Dallari, M. and Francucci, C. (1998). L'esperienza Pedagogica dell'Arte, Florence, La Nuova Italia.

Francucci, C. and Vassalli, P. (2005). Educare all'Arte, Milan, Mondadori Electa

Bertolini, I., (2009). II ritratto attraverso I'“altro specchio": la fotografia, in Francucci, C. and Vassalli, P. (2009). Educare all'Arte: Immagini, Esperienze, Percorsi, Milan, Mondadori Electa

Spadoni, S.: Tratti e Ritratti. [on line] June 2003[Consulted in May 2012]. Available in: <http://www.google. $\mathrm{com} /$ url? sa $=$ t\&rct=j\&q=\&esrc=s\&source=web\&cd=23\&ved=oCFoQFjACOBQ\&url=http\%3A\%2F\%2 Fwww.didart.net\%2FgetFile.php\%3Ff\%3Dtrattieritratti.pdf\&ei=oXG_T67iDZC1hAebz4CZCg\&usg=A FQjCNFZOy-iubhdyrwIpDLd1uyqbuUISQ\&sigz=07FEfMxZeMztZrlHFWrXsQ> 